\title{
Benign Restraint: The SEC's Regulation of Execution Systems
}

\author{
David M. Schizer
}

To the handful of traders who founded the New York Stock Exchange (NYSE) in 1792-and perhaps even to the securities traders of the 1960 's - today's securities markets would be virtually unrecognizable. New communications and data processing technologies, the globalization of investment portfolios, and a surge in trading volume have created new needs and possibilities. As a result, revolutionary advances have occurred in the design and performance of execution systems: the technologies (computers, telephones, modems) and formats (auction-based stock exchanges, dealer-based "over-the-counter" markets, computerized single price auctions) that traders use to conduct trades. These advances enable trades on the NYSE, the regional exchanges, the over-the-counter markets, and emerging computerized execution systems to be conducted more rapidly, more accurately, and more inexpensively than ever before.

Amid this era of transformation, most critics have called upon the Securities Exchange Commission (SEC) to mandate a single type of execution system, ${ }^{1}$ something the SEC has refused to do. Some critics diagnose this reluctance as a symptom of regulatory "capture." For example, Jonathan Macey and David

1. See, e.g., OFFCE OF TECHNOLOGY ASSESSMENT, ELECTRONIC BULLS AND BEARS: U.S. SECURTIES MARKETS AND INFORMATION TECHNOLOGY 7-13, 49-51, 59-60 (1990) [hereinafter ELECTRONIC BULLS \& BEARS] (questioning viability of specialist system); Milton $\mathrm{H}$. Cohen, The National Market System-A Modest Proposal, 46 GEo. WASH. L. REV. 743, 754-89 (1978) (calling on SEC to develop various market links such as a composite quotations system, to promulgate new execution and market-maker rules, and to study issues relating to development of "national market system of the future"); David A. Lipton, Best Execution: The National Market System's Missing Ingredient, 57 NOTRE DAME LAW. 449, 462-63, 499-505 (1982) (faulting SEC for failing to propose a best execution rule, which would require traders to search various markets for the best price); Jonathan R. Macey \& David D. Haddock, Shirking at the SEC: The Failure of the National Market System, 1985 U. ILL. L. REV. 315, 332-37, 361 (criticizing SEC for failing to promote competition among dealers by lifting off-board trading restrictions-rules that require exchange members to trade only on exchange floor); Norman S. Poser, Restructuring the Stock Markets: A Critical Look at the SEC's National Market System, 56 N.Y.U. L. REV. 883, 946 (1981) (criticizing SEC for vacillation and procrastination in developing National Market System and thus advising SEC to reconsider development of system); Joel Seligman, The Future of the National Market System, 10 J. CORP. L. 79, 13739 (1984) (criticizing SEC for failing to promote a universal message switch-a market link that would relay orders to the market displaying the best quote-and competition among dealers markets); Walter Wemer, The SEC as a Market Regulator, 70 VA. L. REV. 755, 770-84 (1984) (criticizing SEC for failing to take more activist stance in developing National Market system and urging "government [to] acquire . . . [the] capability" to develop such a system). 
Haddock suggest that the SEC does not regulate more intrusively because it is unwilling to offend various special interests. ${ }^{2}$

This Note argues that the SEC acted wisely in choosing a strategy of "benign restraint," rather than designating a single, preferred execution system. Although the motives of the SEC are difficult to discern, it is unlikely that the agency has been "captured" by special interests. ${ }^{3}$ Regardless of the SEC's reasons, however, this Note claims that the SEC's restrained regulatory strategy is the best one. To develop this argument, Part I describes the goal pursued by the SEC-insuring that the securities markets will maximize societal wealth-and the problems associated with nurturing such a market. Part II describes recent manifestations of the SEC's restrained regulatory strategy. Part III then considers criticisms of the SEC's approach. Finally, Part IV discusses the advantages of benign restraint.

\section{THE REgULATORY PROBLEM}

\section{A. The Public Interest at Stake}

Securities markets promote a vital public interest-the maximization of society's wealth ${ }^{4}$-by performing five functions. First, they help corporations and governmental bodies raise capital and thus create wealth and jobs. ${ }^{5}$ Second, through "price discovery," capital markets assign a value to the building blocks of the world's economy. Third, these prices influence investment calculations, employment decisions, and the allocation of resources. ${ }^{6}$ Fourth, the markets allow individuals to invest their savings ${ }^{7}$ and to guide management by

2. Macey \& Haddock, supra note 1 , at 315-16.

3. See JAMES D. COX ET AL., SECURTIIES REgULATION 24 (1991); HOMER KRIPKE, THE SEC AND CORPORATE DISClOSURE: REgULATION IN SEARCH OF A PURPOSE 8 (1979); SUSAN M. PHILLIPS \& J. RICHARD ZECHER, THE SEC AND THE PUBLIC INTEREST 5 (1981); Poser, supra note 1, at 946.

4. The argument of this Note should be persuasive to those who believe that wealth maximization is the sole public interest implicated in the regulation of execution systems. This is not an unreasonable belief, in that securities market's raison d'être is to create wealth, not to serve as the ultimate level playing field or the fairest of casinos. Redistributive or faimess goals are better pursued by other means.

Yet this Note's thesis should also be persuasive to those who believe that regulators of execution systems should be concemed with fairness as well as wealth maximization. Indeed, achieving faimess may be an essential prerequisite to achieving wealth maximization. In order to maximize wealth, a market must be perceived as fair. Otherwise, investors will be wary of bringing their capital to the market-a situation not calculated to promote capital formation, price discovery, or the other functions of an effective capital market. See ROBERT A. SCHWARTZ, RESHAPING THE EQUTYY MARKETS 174 (1991). For clarity, this Note speaks of wealth maximization as the public interest involved in the regulation of execution systems. The goal of wealth maximization, however, substantially encompasses the faimess objective.

5. ELECTRONIC BULLS \& BEARS, supra note 1 , at 25.

6. See SANFORD J. GRosSMAN, THE INFORMATIONAL Role OF PRICES (1989). But see Lynn A. Stout, The Unimportance of Being Efficient: An Economic Analysis of Stock Market Pricing and Securities Regulation, $87 \mathrm{MICH}$. L. REv. 613, 696-706 (1988) (challenging allocative efficiency justification for promoting accuracy in pricing).

7. ELECTRONIC BULIS \& BEARs, supra note 1 , at $25,30-31$. 
expressing collective judgments about publicly traded companies. ${ }^{8}$ Finally, capital markets provide jobs to Americans in an era when some other industries are faltering. ${ }^{9}$

\section{B. The Policy Dilemma}

Deciding which execution system promotes wealth maximization most effectively is enormously difficult. Theoreticians, traders, and investors disagree, often heatedly, about which characteristics of an execution system-such as speed, cost, and accuracy-are most important, which mix of attributes would be optimal, and which technologies and structures are most likely to implement this mix.

\section{The Problem of Priorities}

No system is perfect, and attempts to improve a system's performance in one area tend to undermine its performance in others. For example, there is a tradeoff between reliability and cost. To ensure that a system can accommodate uncharacteristically large trading volumes, designers must include considerable excess capacity, an expensive endeavor ${ }^{10}$ Not surprisingly, players assign different values to an execution system's various features. For instance, because program traders earn their living by executing large, precisely timed trades, they emphasize speed more than the average investor does. ${ }^{11}$

When faced with conflicting preferences, regulators must decide whether to prescribe a single mix of characteristics for all trading systems; to require different mixes for different situations; or to elect not to prescribe any mix, thereby allowing private actors to guess investors' preferences and to compete for their patronage.

\section{The Uncertain Path of Technology}

Even if investors valued exactly the same combination of characteristics-and surely they do not-regulators would still have to determine which market structures and technologies would provide that mix most effectively. Choosing the proper technology can be difficult because the capabilities of a technology are typically unknown and unpredictable; before a system is activated, experts often do not agree on how it will perform relative

8. Id. at $25,29-30$.

9. Id. at 25, 31-32.

10. See generally GENERAL ACCOUNTING OFFICE, STOCK MARKET AUTOMATION: EXCHANGES HAVE INCREASED SYSTEMS' CAPACTIIES SNCE THE 1987 MARKET CRASH (1991) [hereinafter STOCK MARKET AUTOMATION].

11. See SCHWARTZ, supra note 4, at 107-10 (describing activities of program traders, including basket trading, portfolio insurance, and index arbitrage). 
to other systems. Moreover, because recent technological growth in the securities industry has been so explosive, any technology chosen is likely to become outmoded rapidly. ${ }^{12}$

\section{The Debate Over Market Structure: Auction vs. Dealer Markets}

In selecting an execution system, regulators would have to choose either the "dealer" or "auction" format. On a dealer market, such as the National Association of Securities Dealers Automated Quotation System (NASDAQ) or the London Stock Exchange, professional traders known as "dealers" or "market-makers" trade with the public. If customers wish to buy, the dealer sells them the security from his own portfolio, and if customers wish to sell, the dealer purchases their securities for himself. The dealer publishes a schedule, the "bid-ask spread," which states the prices at which he will trade. To make a profit, the dealer buys the security at a lower price than he will charge when selling it.

In contrast, on auction markets such as the Tokyo and New York Stock Exchanges, brokers trade as agents rather than as principals. ${ }^{13}$ When a customer wishes to sell, a commission broker on the NYSE does not buy the stock from him, as would a NASDAQ dealer. Rather, the commission broker represents the customer in a search for a broker whose client wishes to buy at the same price. By finding a buyer for his seller, the broker earns a commission. Ultimately, rather than trading with a dealer, the customers on an auction market trade with each other, albeit via agents. ${ }^{14}$

Theoreticians and practitioners clash over the comparative liquidity, accuracy, fairness, and reliability of dealer and auction markets. ${ }^{15}$ In order to designate a particular system, regulators would have to choose a side in this longstanding rivalry.

\section{AN ERA OF BENIGN RESTRAINT}

Faced with a technological revolution, a heated debate over market structure, and a marketplace of investors with diverse preferences, the SEC has so far decided not to decide. It has not designated a preferred execution system and instead has relied on competition within the private sector.

12. See Richard O. Scribner, The Technological Revolution in Securities Trading: Can Regulation Keep Up? in TEChNOLOGY AND THE REGULATION OF FINANCLAL MARKETS 19, $19-21$ (Anthony Saunders \& Lawrence J. White eds., 1986) (surveying changes that technology has effected in marketplace).

13. The NYSE also has elements of a dealer market. Every stock on the NYSE is assigned to a dealer, known as a "specialist," who is responsible for making a market in the stock. As the trader of last resort, he provides the market with liquidity. See Poser, supra note 1, at 890.

14. Id. at 888-93.

15. For further discussion of the relative merits of auction and dealer market structures, see infra notes 79-90 and accompanying text. 
A. A Host of New Trading Systems

By standing aside, the SEC has allowed private firms to generate a cascade of new trading systems: automated systems that publish dealers' spreads, ${ }^{16}$ networks that channel an order from the customer's keyboard to a trading floor, ${ }^{17}$ and even systems that execute orders automatically. ${ }^{18}$

\section{B. The Survival of the NYSE Trading Floor}

Even before the London Stock Exchange closed its trading floor in 1986, the New York Stock Exchange was under pressure to "automate" its trading. ${ }^{19}$ After 1986, criticism of the NYSE intensified, ${ }^{20}$ and the SEC drew fire for refusing to force the NYSE down London's path. ${ }^{21}$

The SEC properly withstood this pressure. The NYSE has not refused to close the trading floor solely to protect its members, though powerful groups on the floor would, of course, resist being replaced by computers. Sound policy reasons militate against imitating London. By automating its trading floor, the London Exchange encountered a host of difficulties, particularly in the clearance and settlement of trades. ${ }^{22}$ Furthermore, even if London's experience had been a success, it would have questionable relevance for the NYSE because while London was a dealer market before closing its floor, the NYSE is essentially an auction market. Dealer markets are easier to automate because they simply depend on the dealer to name her price, which customers may accept or reject. A dealer can just as easily display her quotes on a computer screen as at a trading booth. An auction market, in contrast, requires competitive bidding and negotiation and thus cannot be computerized as readily;

16. NASDAQ is the most widely used of these systems. See Michael J. Simon \& Robert L.D. Colby, The National Market System for Over-the-Counter Stocks, 55 GEO. WASH. L. REV. 17, 34-44 (1986) (recounting history of NASDAQ).

17. After the NYSE introduced the Designated Order Turnaround System (DOT), the first such network, and then the Super-DOT system, an upgraded version, the nation's other exchanges introduced similar systems: Max on the Midwest Stock Exchange, Scorex on the Pacific Exchange, Pace in Philadelphia, and Beacon in Boston. See Saul Hansell, The Wild, Wired World of Electronic Exchanges, INSTITUTIONAL INVESTOR, Sept. 1989, at 91-92.

18. Equity traders can use the Cincinnati StockExchange's National Securities Trading System (NSTS), Instinet's Crossing Network, and Jeffries Company's Posit. The Chicago Mercantile Exchange and the Chicago Board of Trade are developing such systems for trading options, and a system called Portal is available for trades in private placements. See id. at 92-93.

19. See The Balancing Act at the New York Stock Exchange, INSTITUTIONAL INVESTOR, Sept. 1989, at 94 [hereinafter Balancing $A c t$ ].

20. E.g., Jason Forsythe, The Big Board: Boxed in by Automation, INFo. WK., May 20, 1991, at 46; David Kull \& Lee Keough, The House of Games, COMPUTER \& COMM. DECISIONS, Aug. 1988, at 43; Richard L. Stem, A Dwindling Monopoly, FORBEs, May 13, 1991, at 64; Richard L. Stern, "The Market Is a Price, Not a Place," FoRBes, Feb. 5, 1990, at 41 [hereinafter Stem, "The Market Is a Price, Not a Place"]; Chris Welles, Is It Time to Make the Big Board a Black Box?, Bus. WK., Feb. 5, 1990, at 74.

21. See, e.g., Pavan Sahgal, Integration Dream Eludes the National Marketplace, WALL STREET COMPUTER REV., Sept. 1990, at 4.

22. See, e.g., Monica Roman, High Tech Clogs Clearing Systems, AM. BANKER, Dec. 18, 1987, at 16. 
this sort of interaction is not easily duplicated on a screen..$^{23}$ Additionally, if the NYSE had followed London by replacing its auction with an automated dealer format, it would have lost certain advantages available only in auction markets. ${ }^{24}$

Without abandoning the auction format, the NYSE nevertheless used automation to enhance the speed and efficiency of its trading. For example, the "Super-DOT" system, which handles approximately eighty percent of the NYSE's transactional volume, can relay 210 orders to the floor each second and then display them on electronic screens that print prices hundreds of times faster than mechanical printers. ${ }^{25}$

\section{A Restrained Response to the Crash}

The stock market crash of October 19, 1987 created a swirl of pressures on the SEC to take some action, even ill-considered action, as a way of reassuring the public. Government officials generated a frenzy of accusations, studies, and recommendations. ${ }^{26}$ Yet the SEC withstood the temptation, so strong amidst the wreckage left by the crash, to fix things that were not broken.

It is unlikely that execution systems caused the crash. After all, markets across the globe - each with a different execution system - all experienced rapid price declines. ${ }^{27}$ It seems more likely that the market break derived either from a shift in economic fundamentals ${ }^{23}$ or from a sudden loss of investor confidence. ${ }^{29}$ In either case, the initial decline in price was probably

23. See SCHWARTZ, supra note 4, at 80-81 (noting that live auctions convey information-such as the identity of customers placing large orders and the body language and tone of voice of the traders-which is lost when auction is computerized). For further discussion of the complications involved in black box trading, see infra text accompanying notes 91-95.

24. E.g., SchwakTZ, supra note 4, at 60 (noting that price discovery may be less effective on dealer markets than on auction markets). See infra text accompanying notes $79-90$ for further discussion of the relative merits of auction and dealer markets.

25. See SCHWARTZ, supra note 4, at 31-32 (describing Super-DOT).

26. E.g., Financial Market Regulatory Reform, 1988: Hearings on H.R. 4997 Before the Subcomm. on Telecommunications and Finance of the House Comm. on Energy and Commerce, 100th Cong., 2d. Sess. (1988); Oversight Hearings-Matters Relating to the October 19 Market Break, 1988: Hearings Before the Senate Comm. on Agriculture, Nutrition, and Forestry, 100th Cong., 2d. Sess. (1988) [hereinafter Oversight Hearings]; DIVISION OF MARKET REGULATION, U.S. SEC. AND EXCH. COMM'N, THE OCTOBER 1987 MARKET BREAK (1988) [hereinafter SEC's STUDY OF 1987 MARKET BREAK]; GENERAL ACCOUNTING OFFICE, FINANCIAL MARKETS: PRELIMINARY OBSERVATIONS ON THE OCTOBER 1987 CRASH (1988); REPORT OF THE PRESIDENTIAL TASK FORCE ON MARKET MECHANISMS (1988) [hereinafter BRADY COMMIISSION REPORT].

27. Cf. Richard Roll, The International Crash of October 1987, in BLACK MONDAY AND THE FUTURE OF FINANCIAL MARKETS 35 (Robert W. Kamphuis, Jr. et al. eds., 1989) (arguing that worldwide nature of market break is inconsistent with various popular explanations that attribute crash to institutional arrangements existing in only a few markets) [hereinafter ELACK MONDAY].

28. See Eugene F. Fama, Perspectives on October 1987, or, What Did We Learn From the Crash?, in BLACK MONDAY, supra note 27, at 71 (arguing that crash is consistent with traditional understanding of efficient capital markets even if cause of crash cannot be identified).

29. Robert Shiller, Financial Speculation: Economic Efficiency and Public Policy 7 (1991) (unpublished manuscript, on file with author) (market crash of 1987 was "old-fashioned speculative panic"). 
exacerbated by various investment strategies such as portfolio insurance and other types of program trading. These strategies required money managers to sell their holdings when prices dipped below a certain level, thereby creating a vicious cycle. As prices fell, the programs generated sell orders that caused prices to fall further. ${ }^{30}$ Though these strategies may warrant some action in response by the SEC, they relate to the formulation of trades rather than to their execution. Thus, the SEC's restraint was justified because while the problems posed by "program trading" are sometimes confused with those associated with automated execution systems, they are analytically distinct.

While execution systems did not cause the crash, they might nevertheless have performed better. If exchange specialists and NASDAQ market-makers had possessed more capital, they might have slowed the decline of prices slightly ${ }^{31}$ - though no market-maker could have had enough capital to stabilize prices against the onslaught of sell orders then besieging the market. "Circuit breakers," which halt trading in a stock when its price has moved a certain amount, might have helped to dissipate the panic. ${ }^{32}$ Furthermore, investors might have panicked less feverishly had they been confident that the exchanges' trading technologies could handle the heavy volume of the crash. Finally, technological imperfections in the NYSE's execution systems may have disadvantaged small investors. The printers relaying Super-DOT's small orders to the specialists were too slow to accommodate heavy volume. As a result, small orders were backlogged, sometimes for over an hour. ${ }^{33}$ In contrast, large orders (which typically were placed with floor brokers) could be executed without this delay. Moreover, institutional investors had better communications links with traders than small investors. ${ }^{34}$

The private sector needed no encouragement from the SEC to address these weaknesses. The industry was eager to avert another crash and to reassure investors that the markets were functioning smoothly. ${ }^{35}$ As a result, the SEC was able to assume a restrained, supervisory role that relied on the private sector to revamp itself. For example, the NYSE implemented "circuit breakers,; ${ }^{336}$ required specialists to maintain more capital; ${ }^{37}$ spent millions to enhance the reliability of its automated systems; and enhanced the reliability of the Super-DOT printers; increased their number; and replaced some of them

30. Lawrence Harris, The Dangers of Regulatory Overreaction to the October 1987 Crash, 74 CORNELL L. REV. 927 (1989).

31. See ElECTRONC BULLS \& BEARS, supra note 1, at 58-61 (describing performance of specialists and market-makers during crash).

32. Id. at 57-58.

33. SEC's STUDY OF 1987 MARKET BREAK, supra note 26 , at 7:15-16, 7:21-23.

34. Id. at 7:14.

35. Cf. Oversight Hearings, supra note 26, at 275-79 (statement of Richard Grasso, Executive Vice President, Capital Markets, NYSE) (describing efforts undertaken voluntarily by NYSE to avert recurrence of problems associated with crash).

36. SCHWARTZ, supra note 4 , at 44-45.

37. DIVISION OF MARKET REGULATION, U.S. SEC. AND EXCH. COMM'N, MARKET ANALYSIS OF OCTOBER 13 AND 16, 1989, at 16 (1990) [hereinafter SEC'S 1989 MARKET ANALYSIS]. 
with electronic screens ${ }^{38}$ so that small orders would not again be backlogged to the detriment of small investors. ${ }^{39}$

\section{Restrained Regulation of Automation Risk}

The stock market crash highlighted the danger of automation risk: ${ }^{40}$ the vulnerability of trading technologies to overload as a result of heavy volume, manipulation, or computer viruses. In response, the SEC opened an Office of International Trading and Technology ${ }^{41}$ and has suggested ways, in two recent releases, to test for and minimize various automation risks. ${ }^{42}$ Committed to benign restraint, the SEC has made adherence to these suggestions voluntary and has resisted pressure, particularly from the Government Accounting Office (GAO), to expand the size and responsibilities of the new office. ${ }^{43}$

This restrained regulatory posture is appropriate. If the SEC required specific review methods and operating standards, it might prevent the private sector from developing better ones. In addition, private firms presumably have strong incentives to minimize automation risk because unreliable systems are unattractive to customers. ${ }^{44}$ Thus, the private sector needs little encouragement from government in this area.

Indeed, the efforts of the private sector to reduce automation risk have been effective so far. For example, the NYSE's systems performed far better during the market break of 1989-a 250 point plunge in the Dow Jones Industrial Average-than during the crash of 1987. In the 1989 downturn precipitated by the collapse of an attempted takeover of United Airlines, ${ }^{45}$ small orders were not backlogged, and only minor problems emerged in the NYSE's automated systems. ${ }^{46}$

38. Id. at 53,61-62 (describing improvements in NYSE printers and introduction of electronic display

39. Even so, the SEC may occasionally have to intervene in order to protect small investors. See infra note 121 .

40. See, e.g., GenERAL ACCOUNTING OFFIC, FINANCIAL MARKETS: ACTIVE OVERSIGHT OF MARKET AUTOMATION BY SEC AND CFTC NEEDED (1991) [hereinafter ACTIVE OVERSIGET NEEDED] (discussing automation risk).

41. See Mark Arend, Electronic Markets Heighten Regulatory Concerns, WALL STREET COMPUTER REV., Jan. 1991, at 31 (discussing new SEC office).

42. Automated Systems of Self-Regulatory Organizations, Exchange Act Release No. 27,445 [19891990 Transfer Binder] Fed. Sec. L. Rep. (CCH) I 84,505 (Nov. 16, 1989); Automated Systems of SelfRegulatory Organizations, Exchange Act Release No. 29,185 [1990-1991 Transfer Binder] Fed. Sec. L. Rep. (CCH) I 84,733 (May 9, 1991).

43. E.g., ACTTVE OVERSIGHT NEEDED, supra note 40, at 6-8 (urging SEC to regulate automation more vigorously).

44. Cf. David D. Haddock, An Economic Analysis of the Brady Report: Public Interest, Special Interest, or Rent Extraction? 74 CoRNELL L. REV. 841, 851 (1989) (noting that profit motive gives exchanges incentive to avoid repetition of information overload that plagued exchanges during $1987 \mathrm{crash}$ ).

45. SEC's 1989 MARKET ANALYSIS, supra note 37, at 17.

46. Id. at 37-38. 


\section{E. The Restrained Regulation of Proprietary Systems: Delta Options and SPA- works}

Consistent with benign restraint, the SEC has promoted competition through its regulation of "proprietary systems," execution systems that are distinguished by the manner in which they are owned. Proprietary systems are the property of the firm that built them. In contrast, most execution systems are owned by a membership of brokers or dealers. For example, NASDAQ-which is not a proprietary system -is owned by the National Association of Securities Dealers, rather than by Bunker-Ramo, the firm that built the system. ${ }^{47}$

In the last two years, the private sector has created two "proprietary" systems that trade securities in a computerized auction. Three companies-the broker RMJ Options Trading Co., the clearinghouse Delta Government Options Co., and the bank Security Pacific National Trust Co.-created the Delta system for trading options on government securities. The Delta system enables a customer to input orders anonymously, prints them on a computer screen, and invites other customers to respond anonymously via their own computer terminals. "SPA-works," the creation of R. Stephen Wunsch, a former trader at Kidder Peabody, ${ }^{49}$ is a computer network for the trading of NYSE-listed stocks. The system, a "single price auction," accepts a host of orders during a designated time period and then uses sophisticated software to distill a market clearing price from these orders.

The securities industry is divided over the virtues of proprietary systems. Not surprisingly, the exchanges and the over-the-counter markets oppose these potential competitors. Thus, the Chicago Board of Trade and the Chicago Mercantile Exchange sued to block the creation of the Delta system. ${ }^{50}$ Similarly, the NYSE; ${ }^{51}$ AMEX; ${ }^{52}$ NASD; and the Pacific, ${ }^{53}$ Boston, and Midwestern Exchanges publicized their opposition to SPA-works. Yet institutional traders support the proprietary model because they want to develop their own trading systems to avoid paying commissions and spreads. ${ }^{54}$ Another reason to support the proprietary model is that it is uniquely suited to promote

47. See Simon \& Colby, supra note 16 , at 36 (describing design and construction of NASDAQ).

48. Board of Trade v. SEC (Board of Trade I), 883 F.2d. 525, 527 (7th Cir. 1989).

49. Leslie Wayne, A Rock Climber's Reach for the Top on Wall St., N.Y. TMES, Jan. 24, 1991, at D1.

50. See Board of Trade I, 883 F.2d. at 525; Board of Trade v. SEC (Board of Trade II), 923 F.2d. 1270 (7th Cir. 1991).

51. Jayne Levin, Big Board Urges Regulators to Reject Wunsch Exemption; Fears Split Between Institutional, Retail Trading, INVESTMENT DEALERS' DIG., Jan. 14, 1991, at 9; NYSE Disputes SEC's Power to Exempt Wunsch System, INSTITUTIONAL INVESTOR, Jan. 14, 1991, at 7.

52. Jayne Levin, American Stock Exchange Urges SEC to Go Slow on New System; Says Wunsch System Could Handle Huge Volume, INVESTMENT DEALERS' DIG., Dec. 24, 1990, at 6; AMEX Slams Wunsch's Bid for Exemption, WALL STREET LETTER, Dec. 24, 1990, at 9.

53. Hal Lux, Pacific Exchange Criticizes Wunsch Registration Exemption; Cites "Practical Extinction" of Rule, INVESTMIENT DEALERS' DIG., Dec. 10, 1990, at 8.

54. D. Grant Vingoe, New Trading Systems Demand New Regulation; SEC's Handling of Electronic Trading Systems is Shortsighted, INVESTMENT DEALERS' DIG., Apr. 15, 1991, at 26. 
investment in new trading technologies. In a proprietary system, the entrepreneur has greater incentive than in a membership exchange to risk capital to build a new trading system because the entrepreneur retains control over the system and the profits it earns.

To attack the proprietary systems, the exchanges demanded that their fledgling competitors "register" under section 6 of the Securities Exchange Act, ${ }^{55}$ even though (indeed, precisely because) such registration was incompatible with the proprietary format. Registration entails significant administrative costs: registered exchanges must publish and enforce trading rules, gain SEC approval of rule changes, and conform to the other requirements of the Act. Furthermore, the requirements for registration were drafted to apply to membership exchanges rather than to proprietary systems. The Act refers to the exchange's "membership" and to the manner in which members must be treated. ${ }^{56}$ Yet a proprietary system has no membership. It is owned by a private consortium and operated by the employees of the consortium on behalf of customers. Moreover, the rules bar a registered exchange from permitting "unfair discrimination between . . . brokers." system is inherently "discriminatory" because only its owner may use it. Thus, RMJ Options, one of the three firms which owns Delta, is the system's only broker. In order to fulfill the requirements for registration, a proprietary system would have to become a membership exchange, ${ }^{58}$ thus becoming less effective at promoting entrepreneurial investment.

Perhaps to avoid this disincentive and to promote the birth of proprietary competitors, the SEC defended Delta Options and SPA-works. With a narrow reading of section 6 of the Securities Exchange Act, the SEC exempted Delta from registration. Ar first, the SEC tried to avoid the section 6 issue while still allowing Delta to operate. It treated two portions of Delta-the trading and clearance operations-as distinct entities. The SEC authorized the trading arm to commence operations via a no-action letter, which could not be challenged since it was not judicially reviewable. ${ }^{59}$ Then the SEC registered Delta's clearinghouse, reserving judgment on whether the Delta system as a whole was an exchange. ${ }^{60}$

55. 15 U.S.C. § 78(f) (1988).

56. Securities Exchange Act, $\S 6(b)(3), 15$ U.S.C. $\S 78(f)(b)(3)$ (1988), provides that the registered exchange must "assure a fair representation of its members in the selection of its directors."

57. Securities Exchange Act, § 6(b)(5), 15 U.S.C. § 78(f)(b)(5) (1988).

58. Board of Trade II, 923 F.2d. 1270, 1272-73 (7th Cir. 1991).

59. In general, inaction by an administrative agency is not reviewable. See Heckler v. Chaney, 470 U.S. 821, 831 (1985) (articulating presumption of unreviewability for agency inaction). No-action letters, specifically, are not reviewable because they are considered tentative, not final. The SEC agrees to take no action at the time of the letter, so long as conditions are satisfied. The SEC, however, is free to change its position. Board of Trade I, 883 F.2d. 525, 529-30 (7th Cir. 1989). Furthermore, no-action letters are not reviewable because courts consider them a refusal to prosecute, which is a "classic illustration of a decision committed to agency discretion." Id. at 530 .

60. 883 F.2d at 528-29. 
Unwilling to let the SEC duck the section 6 issue, the exchanges challenged this registration in court. They demanded that the SEC resolve whether Delta was an exchange before registering the clearinghouse. According to the exchanges, the clearinghouse and the trading arm were not distinct entities; in fact, the trading arm was the clearinghouse's only customer. Thus, the exchanges argued, the clearinghouse should not be registered if Delta was an exchange that did not comply with section 6; if this was the case, the clearinghouse would be a part of an illegal trading system. ${ }^{61}$ Judge Easterbrook upheld this claim and required the SEC to resolve the predicate issue of whether Delta was an exchange. " $[\mathrm{A}] \mathrm{n}$ agency is not entitled to duck," he scolded, "just because the question is hard." 62

In response, the SEC held that Delta was not an exchange for the purposes of section 6 and, consequently, that the clearinghouse could register separately. In defense of this conclusion, the SEC offered a strained, but plausible, reading of section 6. The section defines an "exchange" as "any organization, association, or group of persons ... which constitutes, maintains, or provides a market place or facilities for bringing together purchasers and sellers of securities or for otherwise performing with respect to securities the functions commonly performed by a stock exchange as that term is generally understood."63 Although the futures exchanges that challenged the SEC's order contended that Delta was clearly an organization which "provides a market place or facilities for bringing together purchasers and sellers of securities," the SEC responded that Delta was not "a stock exchange as the term is generally understood," because it lacked the common features of an exchange, such as specialists and a trading floor. ${ }^{64}$ Judge Posner deferred to the SEC's construction of the statute on the grounds that "[a]n administrative agency has discretion to interpret a statute that is not crystal clear" and that "in this case there is enough play in the statutory joints that [the SEC's] decision must be affirmed." ${ }^{265}$

After its victory regarding Delta, the SEC spared SPA-works from registration by resuscitating section $5(2),{ }^{66}$ an exception to section 6 that had not been used since 1939. Under that exception, the SEC may find that an exchange's volume is too low to justify registration. ${ }^{67}$ Anticipating low volume for SPA-works, the SEC exempted the new system from registration provided that its volume remained lower than that of the regulated exchange with the lowest volume, currently the Cincinnati Stock Exchange, a condition which

\footnotetext{
61. Id. at 533-34.

62. Id. at 536.

63. 15 U.S.C. \& 78c(a)(1) (1988) (emphasis added).

64. Board of Trade II, 923 F.2d. 1270, 1272 (7th Cir. 1991).

65. Id. at 1273.

66. 15 U.S.C. \& 78(e) (1988).

67. Id.
} 
seems likely to continue. ${ }^{68}$ Free of crushing regulatory burdens, SPA-works commenced operations on April 15, $1991 .^{69}$

\section{F. The Promotion of Off-Hours Trading}

As investment portfolios become increasingly global in scope, customers want access to markets at any hour of the day, rather than merely during traditional business hours. Measured by New York time, British investors may wish to trade as early as 3:30 a.m., while Japanese money managers may want to trade well into the night. Americans responding to news in foreign markets may also wish to trade during off-hours. ${ }^{70}$ Since trading is becoming a twenty-four hour affair, ${ }^{71}$ American securities markets can better serve investors by extending their hours. In addition, by failing to lengthen their trading sessions, American markets risk losing volume-and thus jobs-to overseas exchanges. ${ }^{72}$

To extend the hours on America's securities markets, the SEC could depend on market forces. The private sector has an incentive to lengthen its hours, provided that doing so does not excessively increase the cost of operations. Consequently, the NYSE has pledged to have twenty-four hour trading by the year $2000 .{ }^{73}$ With the SEC's approval, ${ }^{74}$ the NYSE opened an automated

68. In 1990, the average daily volume of the Cincinnati Stock Exchange was 1,238,241 shares. Self Regulatory Organizations; Wunsch Auction Systems, Inc.; Order Granting Limited Volume Exemption from Registration as an Exchange under Section 5 of the Securities Exchange Act, Securities Exchange Act Release No. 28,899, 1991 SEC LEXIS 283, at*21 n.40 (Feb. 20, 1991). In contrast, SPA-works' volume on its first day of trading was 300 shares. After Hours Stock Exchange Trades 300 Shares in Session, WaLL ST. J., Apr. 16, 1991, at 21.

69. See Betty Wong, Wunsch Launches U.S. Electronic Trading System, REUTERS FN. REP., Apr. 24, 1991 , at 2.

The saga of proprietary systems is still unfolding. The SEC is committed to its approach and has proposed Rule 15c-10, which codifies the policy developed for Delta and SPA-works. Vingoe, supra note 54, at 26. However, Congressman John Dingell, chairman of the House Energy and Commerce Committee, has questioned the SEC's handling of proprietary systems, Wunsch System May Spur Laws For New "Exchanges," INSTITUTIONAL INVESTOR, Dec. 10, 1990, at 12, and has said that he favors hearings on this issue. Hal Lux \& Jayne Levin, Dingell Said to Push Hearing on Electronic Trading Systems: Exchanges Keep Blasting SEC Decision, INVESTMENT DEALERS' DIG., Mar. 25, 1991, at 8; Wunsch Auction System to Start Up Today; Dingell Watching Closely, SECURTIES WK., Apr. 8, 1991, at 8. SEC commissioner Richard Roberts has indicated support for Dingell's position. SEC's Roberts Joins Dingell in Proprietary Trading System Controversy, SECURTIES WK., May 13, 1991, at 1. The threat of congressional intervention is significant because firms considering investments in proprietary systems might now hesitate.

70. See Mary Billard, Trouble Sleeping? Call a 24-Hour Trading Desk, N.Y. TnIES, May 19, 1991, at F23.

71. See generally OFFCE OF TECHNOLOGY ASSESSMENT, TRADING AROUND THE ClOCK: GLOBAL SECURTIES MARKETS AND INFORMATION TECHNOLOGY (1990).

72. For example, during the hours before the NYSE and NASDAQ open, an increasing volume of NYSE and NASDAQ stocks are traded on the London Stock Exchange, a trend that has alarmed both the exchanges and various government actors. See, e.g., Stephen Labaton, S.E.C. Supports Plan for Earlier Trading of Stocks in the U.S., N.Y. TIMES, Oct. 11, 1991, at A1, D5.

73. Stephen Labaton, Extra Time for Trades Expected, N.Y. TIMES, May 20, 1991, at D1, D8.

74. Order Granting Temporary Approval to Proposed Rule Changes Relating to the New York Stock Exchange's Off Hours Trading Facility, Securities Exchange Act Release No. 29,237, 1991 SEC LEXIS 983 (May 24, 1991); Stephen Labaton, Late Stock Trades Approved by SEC, N.Y. TMMES, May 21, 1991, 
trading system in June $1991,{ }^{75}$ which allows customers to trade stock at the 4 p.m. closing price between 4 p.m. and 5:30 p.m. ${ }^{76}$ In response, the AMEX began developing its own off-hours system, ${ }^{77}$ and the over-the-counter market also extended its hours. The NASD recently initiated an early morning trading session, "NASDAQ International," which opens with London at 3:30 a.m. Eastern Standard Time. ${ }^{78}$

\section{The Limitations of Benign Restraint}

Critics have faulted the SEC's policy of benign restraint for its refusal to choose the "best" execution system, its alleged failure to honor the relevant statutory provisions, its willingness to risk "fragmenting" the markets, and its neglect of small investors. This part evaluates these criticisms.

\section{A. Failure to Select "the Best" Execution System}

A number of commentators, who claim to be able to ascertain which execution system is most effective at maximizing wealth, have attacked the SEC for failing to compel the industry to adopt that format or technology. These commentators rally around three different plans: dealer markets, auction markets, and fully automated "black box" trading.

Jonathan Macey, David Haddock, and Joel Seligman have urged the SEC to promote trading on competitive dealer markets. ${ }^{79}$ They favor competition

at A1.

75. Kurt Eichenwald, A First Step in the March to a 24-Hour Stock Market, N.Y. TMES, June 16, 1991, $\S 4$, at 4 .

76. The plan also reduces the disclosure obligations of program traders during the off-hours session, a move which has been criticized. E.g., Edward H. Fleischman, The Perils of Longer Market Hours, N.Y. TIMES, May 26, 1991, \& 3, at 11 .

The SEC also authorized the NYSE to open a half-hour earlier, though the NYSE later declined to do so because member firms, particularly those with offices on the West Coast, protested that the move would be too expensive. See Floyd Norris, Big Board Won't Add to Hours, N.Y. TMES, July 30, 1991, at D1.

77. SEC Approves AMEX Proposal to Begin its Own After-Hours Trading Program, DAIYY REP. FOR EXECUTIVES (BNA), Aug. 12, 1991, at A6.

78. Labaton, supra note 72, at A1; Floyd Norris, NASDAQ at Night: Risks in Trades in the Dark, N.Y. TMES, Jan. 21, 1992, at D1; see also NASD, NASDAQ International (1990) [hereinafter NASDAQ International] (unpublished pamphlet, on file with author). 39.

79. See Macey \& Haddock, supra note 1 , at $323,332-37,361-62$; Seligman, supra note 1 , at 116,129 -

Though these authors do not explicitly endorse dealer markets, the policies they favor would bring our markets closer to this model of trading. For example, these critics urge the SEC to abolish "off-board trading restrictions"-exchange rules such as NYSE Rule 390 that require members to trade listed securities only on stock exchanges. See Macey \& Haddock, supra note 1, at 323, 332-37; Seligman, supra note 1, at 137-38.

Repealing off-board trading restrictions could promote competition among dealers. Big institutional firms such as Morgan Stanley and Goldman Sachs, which are NYSE members, would become free to trade and make markets in NYSE-listed securities off the floor. Thus, these firms could begin competing with specialists. The current system, based on a single specialist, might give way to a system of competing dealers (if the institutional firms believed they would profit by making markets in listed securities). 
among specialists, big institutional trading houses, and over-the-counter marketmakers for the position of market-maker in particular securities. This competition, they claim, would increase the total supply of capital devoted to market-making, and would also narrow spreads. ${ }^{80}$

For three reasons, these critics have too much faith in dealer markets. Granted, having more capital for market-making in a dealer market will enhance liquidity; when market-makers have more capital, they can engage in more trades without having to add leverage to their positions. Nevertheless, auction markets can generate liquidity in a way that dealer markets cannot; brokers in an auction market bring a steady stream of orders to the trading floor and are thus available to serve as "the other side" to a trade. ${ }^{81}$

In addition, even if heightened competition between dealers would narrow spreads on dealer markets, customers still might not get as good a price as they would have received on an auction market. ${ }^{82}$ Because dealers trade as principals with the customer, they have an incentive to give an inferior price. Admittedly, though, this incentive is tempered by the dealer's fear of losing business to competitors over the long term. But even so, auction brokers' only incentive is to get their customer the best price.

Furthermore, in auction markets, investors can trade "in between the spread" ${ }^{\prime 83}$ to improve pricing accuracy; this rarely happens on a dealer market

This increased competition among dealers advocated by Seligman, Macey, and Haddock could undermine auction trading, however, because off-board trading restrictions provide conditions useful-if not necessary-to such trading. See Kalman J. Cohen et al, An Analysis of the Economic Justification for Consolidation in a Secondary Security Market, 6 J. BANKING \& FIN. 117, 135 (1982) (arguing that with complete elimination of off-board trading restrictions, fragmented dealer markets would replace superior centralized auction system); see also James L. Hamilton, Marketplace Fragmentation, Competition, and the Efficiency of the Stock Exchanges, 34 J. Fov. 171, 171 (1979) (claiming that while off-board trading promotes competition among dealers, it also, through fragmentation, may reduce market efficiency, widen spreads, and increase variance in daily stock prices).

By preventing members from trading off the floor, off-board trading restrictions assure a steady stream of orders for the auction, thereby promoting better liquidity and price discovery. A broker is presumably more likely to find a match for his customer in a large pool of orders than in a small one. Moreover, the securities market price, a consensus judgment about the value of a security, is presumably more likely to factor in all relevant information - and thus be efficient-when it incorporates the judgments of many traders, rather than merely a few. See SCHWARTZ, supra note 4, at 174 (noting that "fragmentation of the order flow to bolster interdealer competition could impair the quality of the market by obscuring the information content of the order flow"). Thus, by advocating the repeal of off-board trading restrictions, all of these critics implicitly are advocating a competitive dealer market model.

80. Macey \& Haddock, supra note 1, at 348-49; Seligman, supra note 1, at 130, 136; see also Kerry Cooper et al., Liquidity, Exchange Listing, and Common Stock Performance (Aug. 1983) (unpublished manuscript, on file with author) (claiming that for a given level of firm capitalization, listing on exchange does not increase liquidity); David A. Dubofsky \& John C. Groth, Exchange Listing and Stock Liquidity, 7 J. FIN. REs. 291 (1984) (claiming that over-the-counter markets provide more liquidity than exchanges).

81. See Simon \& Colby, supra note 16 , at $86-87$ n.428 (citing studies that claim that auction markets provide better liquidity than dealer markets).

82. See id. (citing studies that claim that auction markets provide better retums and a lower cost of capital than dealer markets).

83. Specifically, if the specialist quotes a spread of $1 / 41 / 2$ (meaning that he is prepared to pay a seller $1 / 4$ for a stock and to sell the same stock to a buyer for $1 / 2$ ), two commission brokers are nevertheless free to trade "in between the spread" at 3/8. In so trading, each broker secures an extra 1/8 for his customer. 
because dealers generally post a spread and stick to it. The NYSE claims to save investors billions each year by improving prices, ${ }^{84}$ a benefit that would be lost if the SEC channeled all trading to dealer markets.

Of course, advocates of auction markets could use these arguments to claim that their format is superior, and thus to criticize the SEC for failing to impose it. ${ }^{85}$ Dealer markets, however, offer advantages for certain types of issuers and investors. First, such markets are more accessible because they can operate with fewer people and can therefore remain open for longer hours without incurring prohibitive labor costs. ${ }^{86}$ Moreover, dealer markets afford a better trading environment than auction markets do for thinly capitalized stocks. ${ }^{87}$ Finally, investors who are particularly averse to execution risk-the risk that, within the brief interval between a customer's call to the broker and the execution of her order on the floor, the price will move against her-may prefer to trade in certain dealer markets. ${ }^{88}$ The adverse price movement that creates execution risk is inherent to the auction format. It can derive either from random fluctuations in the market or from the actual effect of the customer's order. ${ }^{89}$ In contrast, in dealer markets that offer "firm" quotes, which oblige dealers to execute trades at the posted price, investors face no execution risk. In this type of dealer market, the bid-ask spread-the compensation investors pay to dealers-serves as an insurance premium risk-averse investors can pay to shift execution risk to dealers, ${ }^{90}$ these investors would therefore object if the SEC imposed auction trading on all market participants.

84. The NYSE has argued that approximately $38 \%$ of trades in NYSE-listed securities were executed on the floor at prices superior to the best available quotation. Reproposal of an Order Exposure Rule, Exchange Act Release No. 19,372 1982 SEC LEXIS 51, at *19-20 (Dec. 23, 1982).

85. Actually, advocates of the auction market have tended not to call upon the SEC to prescribe their format. Instead, these commentators usually only argue that the SEC should not regulate them out of the marketplace by, for example, repealing off-board trading restrictions. See, e.g., Donald L. Calvin, The National Market System: A Successful Adventure in Industry Self-Improvement, 70 VA. L. REV. 785, 795 (1984).

86. Cf. OFFICE OF TECHNOLOGY ASSESSMENT, supra note 71, at 33 (noting that an auction market such as the NYSE "may find it difficult to extend its trading hours because of its labor-intensive trading system"). In fact, the NYSE had to back out of a plan to open 30 minutes earlier partly because such a move was prohibitively expensive. See Norris, supra note 76, at D1. In contrast, dealer markets have been moving rapidly toward 24-hour trading. See generally NASDAQ International, supra note 78; Labaton, supra note 72, at A1; see also text accompanying note 78.

87. In auctions, trades occur only when compatible customer orders meet. When there are fewer customers, as is the case with a thinly capitalized security, their trading preferences are less likely to be compatible. As a result, few trades will occur. Dealer markets, on the other hand, function well even for thinly capitalized securities because dealer markets do not require two customers for each trade. A lone customer can trade with the dealer. See SCHWARTZ, supra note 4, at 137-38 (describing the role of the dealer in facilitating trades). down.

88. A stock "moves against" the buyer by going up in price and moves against the seller by going

89. More specifically, since a bid increases demand in the market as a whole, a large bid can raise the price of the security, sometimes significantly.

90. Marco Pagano \& Ailsa Roell, Auction Markets, Dealership Markets and Execution Risk 13 (Mar. 1990) (unpublished manuscript, on file with author). 
A third camp of critics has urged the SEC to oversee the development of a fully automated ("black box") trading system, which all traders would be required to use. Two varieties of black box trading have been proposed. In the first variety-termed a computerized limit order book (CLOB)-customers input their orders into a giant computer that finds matches. The computer ranks the orders according to their prices. Within price categories, the computer fills bids and offers in the order in which they entered the system. Junius Peake, Morris Mendelson, and R.T. Williams recommend the CLOB model, ${ }^{91}$ and the Cincinnati Stock Exchange utilizes such a system. ${ }^{92}$ The other model, called the single price auction, provides price discovery by duplicating a live auction. Just as on a CLOB, customers input orders into a computer. Instead of matching all compatible orders, however, the computer finds a single marketclearing price and fills all orders for this price. ${ }^{93}$

Advocates of black box trading claim that their computers could fill orders rapidly, cheaply, and accurately. While such systems seem appealing and may eventually dominate securities trading, the SEC should nevertheless be wary of developing or mandating such a system. To do so, the Commission would have to make a difficult choice between the CLOB and the single price auction approach. Though single price auctions provide price discovery, and therefore promote efficiency in resource allocation, they do not offer continuous trading. ${ }^{94}$ Thus, customers must wait until designated trading times. Such delays would be intolerable to many sophisticated investors, especially "program traders," who rely on precisely timed, coordinated, rapid trading.

In contrast, a CLOB offers continuity, but no price discovery, because it never generates a single market-clearing price. A CLOB also fails to protect customers against adverse price movements. The seller may input an offer at 41 when the security is selling at 40 . But if the stock races up to 45 , the seller will nevertheless still sell at 41 . If instead the customer had placed a "market order" with a broker on an auction market, giving the broker discretion to seek the best price, the customer might have sold at 45 . In a sense, if 41 was the

91. Junius W. Peake et al., The National Book System/An Electronically Assisted Auction Market, (1976) (unpublished manuscript, on file with author) (submitted to SEC); see also Simon M. Lome \& Morris Mendelson, Regulation in a National Market Environment, in THE DEREGULATION OF THE BANKING AND SECURITIES INDUSTRY 31, 44-51 (Lawrence G. Goldberg \& Lawrence J. White eds., 1979) (advocating black box trading as the "market form of the future"); Morris Mendelson et al., Toward a Modern Exchange: The Peake-Mendelson-Williams Proposal for an Electronically Assisted Auction Market, in IMPENDING CHANGES FOR SECURITIES MARKETS: WHAT ROLE FOR THE EXCHANGE? 53, 54-60 (Emest Bloch \& Robert A. Schwartz eds., 1979) (proposing electronic market composed of central computer which stores limit orders, prints quotes on national tape, and is linked to national clearing system).

Others have echoed their suggestion. E.g., Forsythe, supra note 20, at $46-50$ (noting the advantages of computerized trading systems); Stern, "The Market is a Price, Not a Place," supra note 20, at 41 (discussing arguments in favor of replacing specialists and trading floors with automation); Welles, supra note 20 , at 74 (suggesting that exchange trading is less efficient than automation).

92. Hansell, supra note 17 , at 92; SCHWARTZ, supra note 4 , at 83.

93. See supra text accompanying notes $49,66-69$ for a discussion of SPA-works, a single-price auction system.

94. ELECTRONIC BULLS \& BEARS, supra note 1 , at 63 . 
customer's reservation price, it may be more socially efficient for him to sell at $41 .{ }^{95}$ Yet because the customer knows that a CLOB offers no protection against adverse price movement, he might be reluctant to trade on such a system unless he could constantly monitor his order and cancel it at will. Because this sort of monitoring is expensive, investors forced to trade on a CLOB would probably engage in fewer trades, thus undermining liquidity. In fact, the Cincinnati. Stock Exchange has attracted only moderate volume, primarily because the cost of monitoring its electronic system is typically higher than the cost of a NYSE commission.

Given that computerized trading still labors under imperfections, the SEC would be ill-advised to force these systems upon traders. If such systems really provide trading that is cheaper, faster, and more accurate, they will quickly dominate a competitive market. Systems with these advantages, but none of the current systems' shortfalls, would overwhelm the flimsy opposition of interest groups displaced by automation. In short, administrative fiat is unnecessary. Private sector competition should channel trading to the most effective execution system.

\section{B. Statutory Constraints}

Critics have alleged not only that benign restraint is an unwise policy, but also that the SEC's statutory mandate bars this restrained approach. Specifically, Seligman, Macey, and Haddock claim that the 1975 National Market System amendments ${ }^{97}$ require the SEC to create a system of competing dealer markets

95. Similarly, some students of corporate takeovers have argued that in the regulation of tender offers, rules that ensure a shareholder her reservation price-but no more-are socially efficient. See, e.g., Alan Schwartz, Search Theory and the Tender Offer Auction, J.L. ECON. \& ORGANIZATION 229, 242-46 (1986) (arguing that takeover auctions are unnecessary to ensure that ownership goes to those who value it most).

96. Poser, supra note 1 , at $926-27$.

97. The following is the text of the relevant portion of the statute:

(1) The Congress finds that-

(A) The securities markets are an important national asset which must be preserved and strengthened.

(B) New data processing and communications techniques create the opportunity for more efficient and effective market operations.

(C) It is in the public interest and appropriate for the protection of investors and the maintenance of fair and orderly markets to assure-

(i) economically efficient execution of securities transactions;

(ii) fair competition among brokers and dealers, among exchange markets, and between exchange markets and markets other than exchange markets;

(iii) the availability to brokers, dealers, and investors of information with respect to quotations for and transactions in securities;

(iv) the practicability of brokers executing investors' orders in the best market; and

(v) an opportunity consistent with the provisions of clauses (i) and (iv) of this subparagraph, for investors' orders to be executed without the participation of a dealer.

(D) The linking of all markets for qualified securities through communication and data processing facilities will foster efficiency, enhance competition, increase the information available to brokers, dealers, and investors, facilitate the offsetting of investors' orders, and contribute to best execution of such orders. 
linked by high-tech communications systems. ${ }^{98}$ In support of their claim, these critics focus on its legislative history and on the events that gave rise to the statute. According to these authors, beginning with its Institutional Investor Study of $1971^{99}$ and continuing in various other policy statements, the SEC called for the creation of a "National Market System" in which various marketmakers would compete. ${ }^{100}$ Congress, they also claim, ratified the SEC's policy in the National Market Amendments.

In support of this claim, Seligman, Macey, and Haddock pick out selections of the legislative history that seem to support this interpretation. ${ }^{101}$ This reading of the statute is questionable, however. The policy of the SEC during the five years before the statute's enactment is far from dispositive because the policy created an intense debate within the industry, and it was this debate that gave rise to the statute. As Donald Calvin has pointed out, Congress staked out a position that was more moderate than the SEC's, deliberately refraining from endorsing dealer markets:

The language of the 1975 Amendments . . is as revealing for what it omits as for what it includes. ...

...

... Congress very carefully avoided calling for the homogenization of all markets into a central market system, a thought that had gained some currency during the discussions, debates, and hearings that preceded the 1975 legislation. ${ }^{102}$

(2) The Commission is directed, therefore, having due regard for the public interest, the protection of investors, and the maintenance of fair and orderly markets, to use its authority under this chapter to facilitate the establishment of a national market system for securities (which may include subsystems for particular types of securities with unique trading characteristics) in accordance with the findings and to carry out the objectives set forth in paragraph (1) of this subsection.

Securities Acts Amendments of 1975, Pub. L. No. 94-29, § 7, 89 Stat. 111 (codified at 15 U.S.C. §§ 78k1(a)(1), 1(a)(2) (1988)).

98. Macey \& Haddock, supra note 1, at 321-24, 331-37 (arguing that 1975 amendment required SEC to repeal off-board trading restrictions and to develop communications and trade reporting systems); Seligman, supra note 1 , at 80-82, 116-30 (claiming that 1975 amendment authorized SEC to remove "barriers to competition" such as off-board trading restrictions).

99. U.S. SEC. AND EXCH. COMM'N, INSTITUTIONAL INVESTOR STUDY REPORT (1971).

100. E.g., Seligman, supra note 1, at $80-82$. Seligman cites a 1972 statement by the SEC that it intended

to

enhance the competition which now takes place among the separate exchange markets and between all of them and the third market (non-exchange member over-the-counter dealers in exchange listed securities) [while] centralizing all buying and selling interest and maximizing market-maker capability ... so that securities can be bought and sold at reasonably continuous and stable prices, and to ensure that each investor will receive the best possible execution of his order, regardless of where it originates.

Id. at 81 (quoting U.S. SEC. AND EXCH. COMM'N, STATEMENT ON THE FUTURE STRUCTURE OF THE SECURITIES MARKET 1-9 (1972)).

101. See Macey \& Haddock, supra note 1, at 322-31; Seligman, supra note 1, at 119-22.

102. Calvin, supra note 85 , at 789,791 (emphasis deleted). 
Instead, the statute appears to allow for a policy of benign restraint. Through the amendments, Congress merely endorsed a set of characteristics and authorized the SEC to nurture markets with these characteristics, without specifying how the SEC was to pursue this goal. A restrained regulatory approach that emphasizes competition seems thoroughly consistent with the statute's text and legislative history. The statute endorsed "fair competition among brokers and dealers, among exchange markets, and between exchange markets and markets other than exchange markets." ${ }^{.103}$ The House Conference report similarly called for a restrained regulatory approach:

The objective [of the statute] is to enhance competition and to allow economic forces, interacting within a fair regulatory field, to arrive at appropriate variations of practices and services. Neither the markets themselves nor the broker-dealer participant in those markets should be forced into a single mold. Market centers should compete and evolve according to their own natural genius and all actions to compel uniformity must be measured and justified as necessary to accomplish the salient purposes of the Securities Exchange Act, assure the maintenance of fair and orderly markets and to provide price protection for the orders of investors. ${ }^{104}$

Avoiding a "single mold" and allowing market centers to "compete and evolve according to their own national genius" sounds very much like benign restraint. In pursuing this strategy, the SEC is well within the parameters of its statutory authority.

\section{The Fragmentation Concern}

Critics have noted that the SEC's restrained regulatory strategy could lead to a "fragmented" securities market, where a given security would be traded in several places, rather than in one centralized location. ${ }^{105}$ Price discovery could be less effective on such a market, and customers might fail to secure the best price for their orders. In a nonfragmented market, where all bids and offers go to the same place, orders are guaranteed to interact and, consequently, orders to buy and sell at the same price are sure to give rise to a trade. In a fragmented marketplace, matching orders may never meet each other if they are routed to different markets. ${ }^{106}$

Some suggest that fragmentation is a frivolous concern, a disingenuous intellectual shield that monopolists in the securities industry use to protect their

103. 15 U.S.C. § 78k-1(a)(1)(C)(ii) (1988).

104. H.R. REP. No. 123, 94th Cong., 1st Sess. 51 (1975), quoted in Calvin, supra note 85, at 792 n.20.

105. See, e.g., Richard L. Stern, The Shrinking of the Big Board, ECONOMIST, Feb. 16, 1991, at 67.

106. See generally ScHWARTZ, supra note 4, at 169-87 (discussing various types of fragmentation and their effects on different market formats). 
positions of privilege. ${ }^{107}$ When the NYSE warns of the perils of fragmentation, this view suggests, it is merely seeking to induce the SEC to protect its market share.

In reality, fragmentation is a genuinely perilous condition ${ }^{108}$ because the inability of complementary orders to meet each other not only can harm the welfare of the parties to the potential transaction-which would increase in a consensual exchange-but also can injure the economy as a whole. Because securities trades signal to the economy the values that investors assign to a particular economic resource, ${ }^{109}$ blocking these trades would deprive the economy of significant messages concerning the most efficient allocation of resources.

Fragmentation can also plunge a securities market into a destructive vicious cycle. Brokers generally are reluctant to reveal their orders on a market unless they expect to find a matching order because their disclosure may induce the market to move against them, particularly if their order is large. ${ }^{110}$ Consequently, if traders view a market as fragmented, they may decide to take their business to another market or to abstain from trading altogether. In this way, the market becomes more fragmented and less liquid. Conceivably, these unfortunate effects could occur in America's securities markets if the SEC's restrained regulatory strategy led to excessive fragmentation. ${ }^{111}$ Indeed, by encouraging the development of new systems, the SEC ensures that some order flow will be diverted from the primary market.

Yet even with these risks, fragmentation is probably the lesser of two evils. While the SEC could immunize the markets against the ills of fragmentation by prescribing a single trading scheme, the agency would run a grave risk of selecting the wrong system from the current candidates. ${ }^{112}$ Moreover, even if the SEC happened to choose the correct system, the chosen trading environment would become less efficient, less reliable, and generally less effective at maximizing societal wealth once it became a legally protected monopoly. In order to have competition, and the technological innovations and

107. See, e.g., Pat Widder, Splintering Market Worries NYSE, CHI. TRIB., Mar. 18, 1991, at C1 (quoting University of Chicago Professor Merton Miller: "[I]t's not at all clear that fragmentation is hurting the public. Monopolists [such as the NYSE] always make that argument.").

108. See, e.g., Cohen et al., supra note 79, at 117, 135 (arguing fragmentation on auction markets reduces overall utility of investors); Haim Mendelson, Consolidation, Fragmentation, and Market Performance, 22 J. FiN. \& QUANTTTATIVE ANALYSIS 189, 197-206 (1987) (claiming that in auction or "clearinghouse" markets, fragmentation reduces volume of trades, increases price variance confronted by individual traders, and reduces expected gains from trading).

109. See GROSSMAN, supra note 6, at 1-2.

110. When a buyer bids above the market price, he may inadvertently drive up this price, thereby trapping himself in a situation in which he must increase his bid still further to trade. SCHWARTZ, supra note 4 , at 308 .

111. Controlling the New Wall Street: Can the SEC Encourage New Trading Systems Without Breaking Up the Market?, INVESTMENT DEALERS' DIG., Jan. 28, 1991, at 18.

112. See infra Part IV. 
lower costs which would accompany it, we should be willing to accept the risk of some fragmentation.

Currently, though, fragmentation is not a serious concern. The volume on America's securities markets is large enough to ensure that liquidity would not dry up even if order flow were channeled away from the primary market. In addition, communications technology now permits traders to monitor and trade on several markets at the same time. Thus, a market will not necessarily be fragmented even when orders have been placed on trading systems thousands of miles apart. ${ }^{113}$

Even if fragmentation were to undermine liquidity, the SEC could remedy the situation without prescribing a single trading format. In fact, the SEC has already experimented with two mechanisms-market links and order exposure rules-that could combat fragmentation in a restrained manner. During the early 1970 's, the SEC linked the nation's exchanges by requiring them to erect an "Intermarket Trading System": a communications network that enabled traders at different exchanges to interact with one another. ${ }^{114}$ The Commission has also tried various order exposure rules that require traders, before trading on a secondary market such as a regional stock exchange, to "expose" their order on the primary market first (e.g., the NYSE for NYSE-listed stocks). Order exposure rules avert fragmentation because they ensure that all orders in a listed security are initially exposed at a single location, the primary market, even though they may ultimately be traded on a secondary market (if, for example, the order is not filled on the primary market). ${ }^{115}$ If necessary, the SEC could, as David Lipton has urged, promulgate a "best execution rule," which would impose an obligation on traders to search the various markets to find the best price for their customers. ${ }^{116} \mathrm{~A}$ combination of these strategies-which would still allow various markets to rely on different trading formats and technologies-should be sufficient to counter the ill effects of fragmentation.

\section{Insufficient Protection for Small Investors}

Critics of the SEC's restrained regulatory policy have pointed to its potential effect on small investors. Relying on competition to shape our execution systems might be ill-advised if the private sector would favor large institutional investors at the expense of small investors. While perhaps

113. Hans R. Stoll, Comments on "An Analysis of the Economic Justification for Consolidation in a Secondary Security Market," 6 J. BANKING \& FIN. 137, 140 (1982) (noting that "execution of transactions does not require face-to-face communication").

114. Charles C. Cox \& Bruce A. Kohn, Regulatory Implications of Computerized Communications in Securities Markets, in TECHNOLOGY AND THE REGULATION OF FINANCIAL MARKETS, supra note 12, at 7 , 10.

115. See Reproposal of an Order Exposure Rule, Exchange Act Release No. 19,372, 1982 SEC LEXIS 51 (Dec. 23, 1982).

116. Lipton, supra note 1, at 499-505. 
distasteful in its own right, such favoritism would also discourage small investors from trading, thus undermining capital formation, price discovery, and the maximization of wealth. ${ }^{177}$ In addition, the small investor might have little choice but to trade in a forum dominated by large investors because any system dominated by small investors would probably not have sufficient volume to provide meaningful liquidity.

Fortunately, competition should yield a trading environment that is reasonably favorable to small investors. Since individuals make up a considerable (albeit shrinking) portion of the investing public, ${ }^{118}$ brokers and dealers have incentives to retain the business of small investors. The NYSE, for example, has rules requiring its members to execute the earlier limit orders of small investors before later orders of large customers. ${ }^{119}$ The Exchange presumably promulgated these rules as a way to attract customers, rather than as a concession to public-spirited regulators. Moreover, large and small investors generally seek similar characteristics in execution systems, characteristics such as liquidity, speed, accuracy, and low cost. Large investors have the incentives and means to gather information about the relative merits of competing systems and should, as sophisticated consumers, be able to induce the owners and operators of execution systems to improve service. ${ }^{120}$ Small investors can then free ride on large investors' expertise and market power. Finally, to the extent that small investors feel disadvantaged, they can simply trade through large investors by placing their money with an intermediary, such as a mutual fund or pension plan. At least for now, the SEC need not intervene to protect small investors. ${ }^{121}$

\section{The Advantages of Benign Restraint}

The SEC has wisely perceived the pitfalls of prescribing a particular execution system. Competition among a host of execution systems provides many advantages for the investor. For example, the NYSE and NASDAQ strive

117. See SCHWARTZ, supra note 4 , at 174 .

118. About $18 \%$ of trades in 1988 were made on behalf of individual investors. ELECTRONIC BULLS \& BEARS, supra note 1 , at 28.

119. SCHWARTZ, supra note 4, at 39-40 (unlike market orders, which are either executed immediately or "killed," limit orders can remain in effect until canceled by the customer).

120. The increasing ability of large shareholders to monitor and negotiate with corporate management has been well documented. See, e.g., Bernard S. Black, Shareholder Passivity Reexamined, 89 MICH. L. REV. 520, 575-95 (1990) (arguing that shareholder activism serves as constraint on management). Similarly, these shareholders should be able to wield comparable influence with owners and operators of execution systems.

121. However, the SEC may ultimately have to intervene to defend small investors. While some features of execution systems are "objectively" desirable, in that they benefit small and large investors alike (e.g., accuracy and reliability), other features benefit large investors at the expense of smaller ones (e.g., the execution of large orders before small ones). To ensure fair markets that can attract capital, the SEC might have to intervene to correct such biases. Such intervention would represent an appropriate-although limited-exception to benign restraint. 
to gain a competitive advantage over one another by upgrading their equipment, lengthening their hours, and trimming their costs. This frenzy of competition has produced a state of the art trading environment, ${ }^{122}$ yielding considerable advantages for customers.

In addition, since investors have varied preferences, a single format cannot satisfy all customers as well as a menu of options can. For instance, investors who particularly wish to avoid execution risk typically favor dealer markets, while customers willing to tolerate some execution risk in order to preserve their chances of improving upon the dealer's spread usually prefer auction markets. ${ }^{123}$ Satisfying both types of investors maximizes society's overall utility.

Since technology and the world economy are constantly evolving, the United States would be well advised to have several trading formats, rather than a single system; this diversity helps forestall the risk that changing conditions will render all the existing systems obsolete. During the early 1970's, for example, technological innovations in computers and communications technology lent new appeal to dealer markets that could capitalize on these advances. ${ }^{124}$ Prior to these technological advances, auction markets were the preferred system, and the NYSE was the undisputed industry leader. ${ }^{125}$ If before this era the SEC had required stocks to be traded only on auction markets, the NASD's dealer markets would have ceased to exist. There would have been no institution poised to capitalize on the advent of these new technologies, and NASDAQ might never have emerged.

The free market should determine the nation's mix of trading systems because the market, unlike the regulator, is adept at aggregating investors' preferences. ${ }^{126}$ While a sampling of investors may describe their predilections to the SEC at a hearing, this data is anecdotal, imprecise, and skewed toward the views of large, organized investors. The surest evidence of an investor's preference is the way she spends her money. By bringing her business to one execution system rather than to another, an investor discloses which format she favors.

Government regulators not only have an imperfect view of investors' preferences, they also cannot clearly assess the capabilities of various trading systems. Since technology and global economic conditions are constantly changing, the planners of a trading system can never be certain about how it will perform, how it will be received, or how other systems would have

122. See supra notes $16-18$ and accompanying text (noting existence of many new systems and improvements in existing systems yielded by private sector competition).

123. See Pagano \& Roell, supra note 90, at 1.

124. See Simon \& Colby, supra note 16, at 34-44 (discussing automation of over-the-counter markets).

125. See id. at 17 (noting that before development of NASDAQ, over-the-counter markets were "a murky backwater, completely overshadowed by the exchange markets").

126. See RICHARD A. POSNER, ECONOMIC ANALYSIS OF LAW 491-507 (3d ed. 1986) (describing the ability of markets to maximize consumer utility). 
compared to the system they chose. No planner has sufficient information to know ex ante, with certainty, that he is making the correct choice. ${ }^{127}$

While private sector planners also confront this obstacle, they can more effectively combat it. The SEC's staff is smaller than the staffs of most firms and considerably smaller than the staffs of all private sector firms in the aggregate. Thus, the market can pour more time and money into research than the government can. ${ }^{128}$ Furthermore, the explorations conducted by the private sector as a whole will be more varied and thorough than the SEC's research. Different firms will adopt varying perspectives on the problem of designing a trading system, while the SEC, a single entity, might have to focus its efforts on just a few angles. In a world with perpetually changing goals, the public is best served by a regulatory system that harnesses the promise offered by a diversity of approaches. Finally, the profit motive provides a better incentive than those that motivate SEC personnel. ${ }^{129}$

The SEC is also at a disadvantage relative to the private sector when correcting its mistakes. In a free market, competitors may implement innovations at will without risking a penalty more severe than the loss of their capital. In contrast, when a regime is controlled by regulators who designate the systems that private actors may use, an innovator must appeal to the regulator for permission to implement his contribution. Progress can become bogged down in a regulatory mire and may never proceed. In addition, by winning over the regulators, whether honestly or otherwise, a firm in a regulated environment could block its competitor's advances to the detriment of the public, while it would be unable to do so in a free market. ${ }^{130}$

In many regulatory areas, the market cannot perform its tasks without abusing the public trust. The regulation of execution systems is unique, however, because the actions of regulators and of private actors both serve the same ultimate purpose: the maximization of societal wealth. ${ }^{131}$ Both regulators

127. See Poser, supra note 1, at 946-51 (noting that the SEC as an institution is better suited to policing existing market structures than to developing new ones); see also Charles E. Lindblom, The 'Science' of Muddling Through, 19 PUB. ADMIN. REV. 79-88 (1959) (noting that information constraints handicap government planning).

128. See Lee B. Spencer, Jr., Comment, in TECHNOLOGY AND THE REgulation of FINANCLAL MARKETS, supra note 12, at 53-55 (arguing that limited funding constrains SEC's ability to regulate "proactively").

129. See JAMES Q. WILSON, BUREAUCRACY: What GOVERNMENT AgENCIES DO AND WHY THEY DO IT 115-36 (1989) (noting that incentives can drive government bureaucracies to suboptimal outcomes).

130. See MANCUR OLSON, THE RISE AND DECLINE OF NATIONS: ECONOMIC GROWTT, STAGFLATION, AND SOCIAL RIGIDITIES 63 (1982) ("Special-interest groups ... slow growth by reducing the rate at which resources are reallocated from one activity or industry to another in response to new technologies or conditions."); see also George J. Stigler, The Theory of Economic Regulation, 2 BELL J. ECON. \& MGMT. SCI. 3 (1971) (arguing that regulation is "actively sought by industry" as a way to protect market share and supracompetitive returns).

131. See PHILLIPS \& ZECHER, supra note 3, at 19 (describing "market failure theory" of securities regulation, which argues that purpose of securities regulation is to promote greater economic efficiency by assuring that prices and outputs are "fully competitive"); see also supra note 4 and text accompanying notes 4-9 (discussing the public interest at stake in the regulation of execution systems). 
and private actors seek to offer efficient, effective capital formation and price discovery. ${ }^{132}$ In recent years, the private sector has effectively promoted the public interest. As described in Part II, private firms have produced a host of new trading systems and have dramatically improved established systems. The fact that the private sector has produced Instinet, Super-DOT, SPA-works, and off-hours trading at the NYSE and NASDAQ demonstrates its ability to improve the markets, and thus to advance the public interest.

Of course, regulators practicing benign restraint will still play an important role. They must ensure that the incentives of firms operating execution systems continue to be aligned with the public interest. ${ }^{133}$ Thus, if execution systems began unfairly discriminating against small investors, the SEC should curtail such practices. ${ }^{134}$ Moreover, the SEC should affirmatively encourage competition among execution systems. At times, it may have to knock down barriers and assist fledgling competitors-as it did with Delta Options and SPAworks through liberal statutory interpretation. ${ }^{135}$ These are limited exceptions to benign restraint, however.

When the market will not pursue the public interest, regulation may be essential. Regulation is inappropriate, however, when the market can advance the public interest more effectively than a public sector planner can, as is the case for execution systems. Private sector competition will yield a smoothly functioning market. Intrusive actions by regulators-who have only limited resources and imperfect information-would, in most cases, merely obstruct progress. Thus, critics who fault the SEC for regulating too "passively" are misguided. In the regulation of execution systems, benign restraint is the wisest course.

132. See, e.g., ELECTRONIC BULLS \& BEARS, supra note 1, at 6 (suggesting that honest market participants and general public share same objectives).

133. Id. (noting that government may have to intervene when "self-interests of market participants create resistance to desirable market improvements or modemization").

134. Since small investors free ride on large investors' research and do not offer economies of scale in trading, some differential treatment may be justified. See supra note 121 and accompanying text (discussing protection of small investors).

135. See supra text accompanying notes 59-69. 
